\title{
p-ISSN 2302-0970 \\ e-ISSN 2723-0201 \\ EFEKTIVITAS PROGRAM BANTUAN PANGAN NON TUNAI TERHADAP KESEJAHTERAAN MASYARAKAT DESA MADDENRA KECAMATAN KULO KABUPATEN SIDENRENG RAPPANG
}

\author{
1)Syafruddin, 2)Muhammad Ikbal, ${ }^{3)}$ Azis Kalrah \\ Fakultas IImu Sosial dan IImu Politik Universitas Muhammadiyah Sidenreng Rappang \\ syafruddin43172034inter@gmail.com \\ aziskalrah@gmail.com
}

\begin{abstract}
Abstrak
Penelitian ini bertujuan untuk mengetahui efektivitas program bantuan pangan non tunai terhadap kesejahteraan masyarkat di Desa Maddenra Kecamatan Kulo Kabupaten Sidenreng Rappang. Populasi penelitian ini sejumlah 111 masyarakat (keluarga penerima manfaat) sedangkan jumlah sampel 55 masyarakat (keluarga penerima manfaat) orang. Teknik pengumpulan data yang digunakan dalam penelitian ini adalah observasi, wawancara, kuisioner dan studi pustaka. Teknik analisis data yang digunakan uji validitas dan uji reliabilitas data, dan regresi linear sederhana dan pengujian hipotesis dengan bantuan aplikasi SPSS versi 21. Hasil penelitian menunjukkan bahwa Efektivitas Program Bantuan Pangan Non Tunai di Desa Maddenra dengan persentase $56 \%$ berada pada kategori kurang baik. Kesejahteraan Masyarakat di Desa Maddenra dengan persentase $60 \%$ berada pada kategori kurang baik. Berdasarkan nilai thitung $>$ ttabel atau $3.305>2,008$ maka H0 ditolak dan $\mathrm{Ha}$ diterima, artinya signifikan memiliki pengaruh sebesar $17,6 \%$ besarnya pengaruh variabel $\mathrm{X}$ terhadap variabel $\mathrm{Y}$.
\end{abstract}

Kata Kunci: Efektivitas dan Kesejahteraan Masyarakat

\begin{abstract}
This study aims to determine the effectiveness of the non-cash food assistance program on the welfare of the community in Maddenra Village, Kulo District, Sidenreng Rappang Regency. The population of this study is 111 people (beneficiary families) while the sample size is 55 people (beneficiary families). Data collection techniques used in this study were observation, interviews, questionnaires and literature study. The data analysis technique used was validity test and data reliability test, and simple linear regression and hypothesis testing with the help of SPSS version 21 application. The results showed that the effectiveness of the Non-Cash Food Assistance Program in Maddenra Village with a percentage of $56 \%$ was in the poor category. Community welfare in Maddenra Village with a percentage of $58 \%$ is in the poor category. Based on the value of tcount $>$ ttable or 3,305 > 2,008, then $\mathrm{HO}$ is rejected and $\mathrm{Ha}$ is accepted, meaning that it has a significant effect of $17,6 \%$, the magnitude of the effect of variable $X$ on variable $Y$.
\end{abstract}

Keywords : Effectiveness, and Community Welfare

JIA | Volume 9 | Nomor 2 | Edisi Agustus 2021 


\section{A. PENDAHULUAN}

Sejak mula kemerdekaan bangsa Indonesia, pemerintah telah memiliki kepedulian yang sangat besar kepada warga Indonesia demi terciptanya warga yang adil serta makmur sebagaimana yang sudah diamanatkan dalam alinea ke 4 UndangUndang Dasar Tahun 1945. Perihal ini tercermin dari bermacam program pembangunan yang selama ini ditunjukan serta diperuntukan guna memberikan kepedulian besar terhadap upaya penanggulangan permasalahan perekonomian, sebab pada dasarnya pembangunan yang dilakukan bertujuan guna tingkatkan kesejahteraan masyarakat.

Kesejahteraan ataupun sejahtera bagi sisi ekonomi ialah orang yang mempunyai pemasukan serta kekayaan yang berlimpah sebaliknya sejahtera menurut Kamus Besar Bahasa Indonesia merujuk pada makna suasana yang nyaman, sentosa, serta makmur. Dari ketiga kata yang mencakup makna sejahtera tersebut sehingga hidup dikatakan sejahtera apabila paling tidak penuhi 3 persyaratan ialah: (a) terbebas dari rasa khawatir serta takut (yang berarti nyaman), (b) terbebas dari kesukaran (yang berarti sentosa), serta (c) serba kecukupan (yang berarti makmur). (Alfian \& Sumarni, 2020).

Menurut Undang- undang Nomor 11 tahun 2009, kesejahteraan sosial merupakan keadaan terpenuhnya kebutuhan material, spiritual, dan sosial warga negara agar bisa hidup layak serta sanggup meningkatkan diri, sehingga bisa melakukan tugas sosialnya. Arifin dan Soesatyo ( 2020: 41- 42), menjelaskan kesejahteraan merupakan sesuatu kondisi dimana terpenuhinya kebutuhan warga secara baik, baik kebutuhan material (sandang, pangan, serta papan) ataupun kebutuhan non material( pendidikan, kesehatan, serta tempat tinggal).

Kesejahteraan sangat erat hubungannya dengan jumlah penduduk miskin. Kata miskin bisa diartikan dengan orang yang tidak mempunyai ataupun mempunyai suatu tetapi tidak tercukupi, ataupun orang yang terbuat diam oleh kefakiran dan bisa pula dimaksud dengan orang yang hina serta lemah. Tidak hanya itu, kata miskin pula bisa diartikan sebagai orang yang tidak mempunyai apa- apa serta sebagian orang pula berpendapat bahwa miskin adalah orang yang tidak mempunyai suatu yang dapat mencukupi kebutuhan hidupnya.

Kemiskinan merupakan sesuatu keadaan kehidupan serba kekurangan yang dirasakan seorang ataupun suatu keluarga sehingga tidak sanggup memenuhi kebutuhan minimun untuk dirinya. Kebutuhan minimun tersebut meliputi kebutuhan untuk makanan paling utama energi kalori yang wajib dipenuhi seorang agar sanggup bekerja guna mendapatkan penghasilan. Menurut Badan Pusat Statistik, masyarakat dikatakan miskin apabila sumber penghasilan kepala rumah tangga dengan pendapatan dibawah Rp.600.000,00 per bulan. Rahadian (2010), mengidentifikasi salah satu kasus yang dialami secara sungguh- sungguh oleh tiap negara di dunia merupakan permasalahan kemiskinan. Dimensi kemiskinan sangat luas serta mampu terjadi dimana saja. Dalam menanggulangi permasalahan kemiskinan pemerintah senantiasa membuat programprogram dalam penanggulangan kemiskinan dari tahun ke tahun, usaha pemerintah dalam penanggulangan kemiskinan sangat sungguhsungguh bahkan merupakan salah satu program prioritas terlebih khusus pemerintah. (Gultom, Kindangen, \& Kawung, 2020)

Program-program yang dilaksanakan dalam upaya pengentasan kemiskinan belum bisa memberikan dampak besar, sehingga tujuan dari pembangunan nasional terkait permasalahan pemerataan kesejahteraan masyarakat masih menjadi permasalahan berkelanjutan. Oleh sebab itu pemerintah membentuk program yang disebut Program Bantuan Pangan Non Tunai (BPNT) guna pemerataan kesejahteraan masyarakat. Berkaitan dengan penerapan Program Bantuan Pangan Non Tunai yang ada di Desa Maddenra Kecamatan Kulo Kabupaten Sidenreng Rappang ini didasarkan pada tingginya jumlah rumah tangga miskin. Guna menunjang penerapan program Bantuan Pangan Non Tunai, sehingga Presiden Republik Indonesia menetapkan Peraturan Presiden Republik Indonesia No 63 Tahun 2017 tentang Penyaluran Bantuan Sosial Secara Non Tunai. Program ini diharapkan sanggup mengurangi beban pengeluaran masyarakat yang tergolong sebagai keluarga penerima manfaat melalui pemenuhan sebagian kebutuhan pangan serta untuk meningkatkan kesejahteraan masyarakat. Program Bantuan Pangan Non Tunai yang diselenggarakan oleh pemerintah dalam 
rangka untuk meningkatkan efektivitas dan efisiensi, ketepatan sasaran penerima bantuan serta mendorong keuangan inklusif.

Pemerintah Desa Maddenra Kecamatan Kulo Kabupaten Sidenreng Rappang mulai melaksanakan Program Bantuan Pangan Non Tunai (BPNT) pada tahun 2017. Program Bantuan Pangan Non Tuani ialah program bantuan pangan yang disalurkan secara non tunai dari pemerintah kepada masyarakat yang tergolong sebagai penerima manfaat melalui mekanisme akun elektronik yang digunakan untuk membeli bahan pangan di toko/ warung yang sudah berkolaborasi dengan Bank Penyalur yang disebut Ewarong. Besaran BPNT ialah Rp 110. 000/ KPM/ Bulan. Bantuan ini tidak bisa diambil secara tunai serta hanya dapat ditukarkan dengan beras serta telur sesuai dengan kebutuhan yang disediakan oleh E- warong. Tujuan ditukarkannya dengan beras serta telur supaya kebutuhan gizi karbohidrat serta protein masyarakat tercukupi.

Desa Maddenra merupakan salah satu desa yang terletak di Kecamatan Kulo Kabupaten Sidenreng Rappang, juga menerapkan Program Bantuan Pangan Non Tunai untuk membantu masyarakat. Adapun jumlah Kepala Keluarga( KK) penerima Bantuan Pangan Non Tunai di Desa Maddenra Kecamatan Kulo Kabupaten Sidenreng Rappang mengalami kenaikan dari tahun 2019 ke tahun 2020.

Keberhasilan program lebih efektif harus dijalankan sesuai dengan peraturan yang berlaku terkait pelaksanaan Program Bantuan Pangan Non Tunai (BPNT) khususnya di Desa Maddenra Kecamatan Kulo Kabupaten Sidenreng Rappang ada beberapa identifikasi permasalahan antara lain:

1. Data yang digunakan untuk penerima Program Bantuan Pangan Non Tunai masih menggunakan data lama sehingga banyak yang tidak tepat sasaran.

2. Kurangnya pembinaan dan pemberdayaan keluarga yang dilakukan oleh Pelaksana Program Bantuan Pangan Non Tunai.

3. Ketetapatan waktu penyaluran bantuan yang tidak sesuai dengan waktu yang ditetapkan.

Berdasarkan fenomena diatas bahwa cara untuk menggapai keberhasilan suatu program dengan menentukan efektivitas program tersebut. Sutrisno (2007: 125) suatu program dapat diukur melalui 6 indikator, antara lain: 1) Ketepatan sasaran, 2)
Pemahaman program, 3) Ketepatan waktu, 4) Tercapainya tujuan serta ,5) Perubahan nyata. (Darmawan \& Adiwidjaja, 2019). Maka bersumber pada uraian latar belakang di atas peneliti tertarik untuk melakukan penelitian dengan judul "Efektivitas Program Bantuan Pangan Non Tunai terhadap Kesejahteraan Masyarakat di Desa Maddenra Kecamatan Kulo Kabupaten Sidenreng Rappang".

Etzioni dalam Simamora $(2009 ; 31)$ Efektivitas merupakan tingkatan keberhasilan dalam menggapai tujuan ataupun target yang sudah didetetapkan sebelumnya. Sondang $P$. Siagian (2001:24) dalam bukunya“ manajemen sumber energi manusia membagikan definisi selaku berikut:" Efektivitas merupakan pemanfaatan sumber daya, sarana serta prasarana dalam jumlah tertentu yang secara sadar ditetapkan sebelumnya untuk menghasilkan sejumlah barang atas jasa kegiatan yang dijalankannya. Efektivitas menunjukkan keberhasilan dari segi tercapai tidaknya target.(Fahreza, Arifin, \& Suryani, 2019). Menurut Makmur (2011:7) mengukur efektivitas suatu program dapat dilakukan dengan Ketepatan penentuan waktu, ketepatan dalam menentukan pilihan, ketepatan dalam menentukan tujuan, dan ketepatan sasaran.

Menurut BPS Indikator Kesejahteraan Rakyat 2019 merupakan publikasi tahunan Badan Pusat Statistik (BPS) yang menyajikan tingkat perkembangan kesejahteraan rakyat Indonesia antar waktu serta perbandingannya antar provinsi ataupun wilayah tempat tinggal (perkotaan dan perdesaan). Publikasi ini menyajikan bermacam aspek kesejahteraan yang informasinya ada serta terukur. Untuk memudahkan interpretasi, perubahan taraf kesejahteraan dikaji menurut delapan bidang yang mencakup kependudukan, kesehatan dan gizi, pendidikan, ketenagakerjaan, taraf dan pola konsumsi, perumahan dan lingkungan, kemiskinan, dan sosial lainnya yang menjadi acuan dalam upaya peningkatan kualitas hidup. Arifin dan Soesatyo bahwa kesejahteraan adalah dimana suatu keadaan terpenuhinya kebutuhan masyarakat secara baik, baik kebutuhan material (pangan, sandang, dan papan) maupun kebutuhan non material (pendidikan, kesehatan, dan tempat tinggal). 


\section{B. METODE PENELITIAN}

Jenis penelitian yang digunakan pada penelitian ini adalah jenis penelitian deskriptif kuantitatif. Adapun populasi yang dijadikan penulis agar mendapatkan data dan informasi secara maksimal yaitu dengan menjadikan seluruh kepala rumah tangga yang menerima Bantuan Pangan Non Tunai dengan jumlah sebanyak 111 kepala keluarga, teknik pengambilan sampel menggunakan non probability sampling, dan teknik penarikan sampel menggunakan rumus slovin dengan tingkat kesalahan $10 \%$, jadi jumlah sampel dalam hal ini sebanyak 53 KK. Teknik pengumpulan data melalui observasi, wawancara, dokumentasi, dan kuesioner, sedangkan teknik analisis data menggunakan analisis tabulasi frekuensi uji kualitas data, dan regresi linear sederhana dan pengujian hipotesis.

\section{HASIL DAN PEMBAHASAN}

Kesesuaian sasaran Program Bantuan pangan Non Tunai di Desa Maddenra bahwa dari 53 jumlah responden, 3 orang atau 5,6\% responden menjawab sangat baik, 18 orang atau $33,9 \%$ responden menjawab baik, 24 orang atau $45,2 \%$ responden menjawab kurang baik, 8 orang atau $15,0 \%$ responden menjawab tidak baik dan tidak ada responden menjawab sangat tidak baik. Rata-rata persentase sebesar $66 \%$ yaitu ketepatan sasaran, sehingga dapat disimpulkan bahwa ketepatan sasaran program Bantuan Pangan Non Tunai di Desa Maddenra dapat dikatakan baik. Faktor ketepatan sasaran program Bantuan Pangan Non Tunai (BPNT) di Desa Maddenra Kecamatan Kulo belum sepenuhnya sesuai dengan kriteria penerima bantuan dan masih ada masyarakat yang tidak layak mendapatkan bantuan sesuai dengan hasil olah data kuesioner namun dari hasil rata-rata persentase diperoleh hasil $66 \%$ atau dikategorikan baik. Namun untuk mencapai $100 \%$ diperlukan adanya peningkatan informasi/data masyarakat yang valid, pengawasan program butuh dipantau lebih jauh seperti pihak pemerintah melakukan pembaharuan data tentang keadaan masyarakat yang menerima bantuan sehingga program bisa berjalan sebagaimana yang diharapkan serta dapat meminimalisir penyalahgunaan bantuan dari pemerintah, kasus yang terkadang timbul yakni penerima bantuan yang dulunya kurang mampu namun sekarang sudah mampu dalam memenuhi kebutuhannya serta masyarakat yang dulunya sanggup memenuhi kebutuhannya namun sekarang tidak sanggup. Sepatutnya penerima yang betul-betul telah sanggup memenuhi kebutuhannya mengundurkan diri sebagai daftar penerima bantuan.

Masyarakat memahami kegiatan Program Bantuan Pangan Non Tunai di Desa Maddenra bahwa dari 53 jumlah responden, 2 orang atau $3,7 \%$ responden menjawab sangat baik, 12 orang atau $22,6 \%$ responden menjawab baik, 28 orang atau $52,8 \%$ responden menjawab kurang baik, 11 orang atau $20,7 \%$ responden menjawab tidak baik dan tidak ada responden menjawab sangat tidak baik. Rata-rata persentase sebesar $60 \%$ yaitu pemahaman program, sehingga dapat disimpulkan bahwa pemahaman masyarakat (keluarga penerima manfaat) tentang program Bantuan Pangan Non Tunai di Desa Maddenra dapat dikatakan kurang baik. Pemahaman Program Bantuan Pangan Non Tunai kepada masyarakat berasal dari Pendaamping TKSK (Tenaga Kesejahteraan Sosial Kecamatan) informasi dari Dinas Sosial Kabupaten Sidenreng Rappang, pendamping TKSK memberitahukan kepada masyarakat penerima bantuan yang ditemuinya saja atau dapat dikatakan bahwa tidak adanya sosialisasi atau pertemuan antara pendamping dengan masyarakat penerima bantuan. Ditarik kesimpulan bahwa sebagian masyarakat penerima kurang mampu memahami program bantuan pangan non tunai.

Waktu penyaluran sesuai dengan rencana distribusi Program Bantuan Pangan Non Tunai di Desa Maddenra, bahwa dari 53 jumlah responden, tidak ada responden menjawab sangat baik, 4 orang atau $7,5 \%$ responden menjawab baik, 17 orang atau $32,0 \%$ responden menjawab kurang baik, 22 orang atau $41,5 \%$ responden menjawab tidak baik dan 10 orang atau $18,8 \%$ responden menjawab sangat tidak baik. Rata-rata persentase sebesar $44 \%$ yaitu ketepatan waktu, sehingga dapat disimpulkan bahwa ketepatan waktu penyaluran program Bantuan Pangan Non Tunai di Desa Maddenra dapat dikatakan kurang baik. Distribusi/penyaluran Bantuan Pangan Non Tunai terlambat dari jadwal yang sudah disepakati bersama, hal ini dikarenakan semenjak adanya kasus covid-19 di Indonesia, namun sebelumnya rutin. Dapat ditarik kesimpulan bahwa ketepatan waktu penyaluran bantuan tidak berjalan 
sebagaimana mestinya atau sesuai jadwal yang telah ditentukan.

Manfaat bagi masyarakat Program Bantuan Pangan Non Tunai di Desa Maddenra, bahwa dari 53 jumlah responden, 1 orang atau 1,8\% responden menjawab sangat baik, 12 orang atau $22,6 \%$ responden menjawab baik, 31 orang atau $58,4 \%$ responden menjawab kurang baik, 9 orang atau $16,9 \%$ responden menjawab tidak baik dan tidak ada responden menjawab sangat tidak baik. Rata-rata persentase sebesar $60 \%$ yaitu pencapaian tujuan, sehingga dapat disimpulkan bahwa pencapaian tujuan penyaluran program Bantuan Pangan Non Tunai di Desa Maddenra dapat dikatakan kurang baik. Adanya program Bantuan Pangan Non Tunai yang diselenggarakan pemerintah, masyarakat yang kurang mampu untuk memenuhi kebutuhannya sangat terbantu untuk memenuhi kebutuhan setiap harinya, beban ekonomi berkurang, masyarakat juga dapat memilih kebutuhannya sendiri di E-Warong sesuai dengan besaran saldo yang diterima sebesar Rp. 110.000 dengan menukarkan kebutuhan pangan seperti beras, tempe, tahu, ikan, dan daging ayam. Ditarik kesimpulan bahwa pencapaian tujuan cukup efektif dengan melihat pendapat masyarakat penerima bantuan dari program Bantuan Pangan Non Tunai yang diselenggarakan pemerintah.

Memberikan suatu perubahan kondisi sosial ekonomi masyarakat sesudah menerima Program Bantuan Pangan Non Tunai di Desa Maddenra, bahwa dari 53 jumlah responden, 2 orang atau $3,7 \%$ responden menjawab sangat baik, 8 orang atau $15,2 \%$ responden menjawab baik, 20 orang atau $37,7 \%$ responden menjawab kurang baik, 23 orang atau $43,3 \%$ responden menjawab tidak baik dan tidak responden menjawab sangat tidak baik. Rata-rata persentase sebesar $54 \%$ yaitu perubahan nyata, sehingga dapat disimpulkan bahwa perubahan nyata kondisi sosial ekonomi masyarakat program Bantuan Pangan Non Tunai di Desa Maddenra dapat dikatakan kurang baik. Perubahan nyata ialah suatu wujud perubahan yang dialami oleh seorang ataupun kelompok terkait penerapan program yang sudah dijalankan. Perubahan nyata bisa menimbulkan dampak positif ataupun dampak negatif, tegantung dari proses penerapan yang dilakukan oleh pihak-pihak terkait agar penerapan kegiatan dapat berjalan sesuai dengan syarat yang telah ditetapkan. Perubahan nyata yang dulunya masyarakat penerima bantuan kurang sekali dalam memnuhi kebutuhan pangan, sandang dan papannya. Dengan adanya program Bantuan Pangan Non Tunai dulunya masyarakat susah dalam memenuhi kebutuhan gizi proteinnya dan sekarang kebutuhan gizi tersebut dapat diperbaiki namun tidak setiap harinya karena adanya program Bantuan Pagan Non tunai.

Hasil akumulasi dari 5 pertanyaan pada variabel efektivitas program bantuan pangan non tunai di atas, maka diperoleh rata-rata hasil persentase yaitu $56 \%$. Jadi dapat ditarik kesimpulan bahwa pada efektivitas program bantuan pangan non tunai di Desa Maddenra Kecamatan Kulo Kabupaten Sidenreng Rappang dikategorikan kurang baik.

Kebutuhan makan terpenuhi sehari-hari masyarakat Desa Maddenra, bahwa dari 53 jumlah responden, 1 orang atau 1,8\% responden menjawab baik, 14 orang atau $26,4 \%$ responden manjawab baik, 24 orang atau $45,2 \%$ responden menjawab kurang baik, 14 orang atau $26,4 \%$ responden menjawab tidak baik dan tidak ada responden menjawab sangat tidak baik. Rata-rata persentase sebesar $60 \%$ yaitu kebutuhan pangan, sehingga dapat disimpulkan bahwa kesejahteraan masyarakat dalam memenuhi kebutuhan makan setiap harinya di Desa Maddenra dapat dikatakan kurang baik. Kebutuhan pangan masyarakat Desa Maddenra dikatakan kurang baik berdasarkan hasil olah data kuesioner. memenuhi kebutuhan pangan seperti kebutuhan karbohidrat setiap harinya cukup baik, namun untuk memenuhi kebutuhan gizi protein (telur, tempe, ikan, dan sebagainya) masih kurang untuk memenuhi kebutuhan sehari-harinya.

Kebutuhan pakaian terpenuhi oleh masyarakat Desa Maddenra, bahwa dari 53 jumlah responden, 2 orang atau 3,7\% responden menjawab sangat baik, 15 orang atau $28,3 \%$ responden menjawab baik, 21 orang atau $39,6 \%$ responden menjawab kurang baik, 15 orang atau $28,3 \%$ responden menjawab tidak baik dan tidak ada responden menjawab sangat tidak baik. Rata-rata persentase sebesar $60 \%$ yaitu kebutuhan pakaian sehari-hari, sehingga dapat disimpulkan bahwa kebutuhan pakaian seharihari masyarakat di Desa Maddenra dapat dikatakan kurang baik. Kebutuhan sandang masyarakat Desa Maddenra dikatakan kurang baik berdasarkan hasil olah data kuesioner. 
Dari hasil wawancara yang dilakukan saat peneliti turun melakukan penelitian dapat ditarik kesimpulan bahwa untuk memenuhi kebutuhan pakaian masyarakat setiap harinya dapat dikatakan cukup, namun untuk pakaian masyarakat ke pesta masih kurang.

Kondisi rumah masyarakat Desa Maddenra, bahwa dari 53 jumlah responden, 2 orang atau $3,7 \%$ responden menjawab sangat baik, 15 orang atau $28,3 \%$ responden menjawab baik, 20 orang atau $37,7 \%$ responden menjawab kurang baik, 16 orang atau $30,1 \%$ responden menjawab tidak baik dan tidak ada responden menjawab sangat tidak baik. Rata-rata persentase sebesar $60 \%$ yaitu kondisi rumah, sehingga dapat disimpulkan bahwa kondisi rumah masyarakat di Desa Maddenra dapat dikatakan kurang baik. Kebutuhan papan masyarakat Desa Maddenra dikatakan kurang baik berdasarkan hasil olah data kuesioner. Dari hasil wawancara yang dilakukan dapat ditarik kesimpulan bahwa kondisi rumah masyarakat penerima bantuan seperti atap, lantai, dan dinding di titik-titik tertentu harus diganti karena sudah rusak.

Berdasarkan hasil data rekapitulasi kuisioner penelitian yang dilakukan di Desa Maddenra Kecamatan Kulo Kabupaten Sidenreng Rappang, pada efektivitas program bantuan pangan non tunai diperoleh persentase yaitu $56 \%$ dengan kategori kurang baik, hal ini menunjukkan bahwa efektivitas program bantuan pangan non tunai yang seharusnya mencapai $100 \%$ namun terdapat $44 \%$ yang tidak tercapai. Menurut Sutrisno (2007:125) mengemukakan bahwa terdapat lima indikator yang perlu dipenuhi dalam efektivitas program yaitu ketepatan sasaran, pemahaman program, ketetpatan waktu, tercapainya tujuan, dan perubahan nyata.

Dilihat dari item kuisioner dalam penelitian diperoleh data responden bahwa indikator ketepatan sasaran dengan persentase $66 \%$ dalam kategori baik, indikator pemahaman program dengan persentase $60 \%$ dalam kategori kurang baik, indikator ketepatan waktu dengan persentase $44 \%$ dalam kategori kurang baik, indikator pencapaian tujuan dengan persentase $60 \%$ dalam kategori kurang baik, dan indikator perubahan nyata dengan persentase $54 \%$ dalam kategori kurang baik. Dengan melihat hasil persentase terendah dari penjabaran tersebut dapat dikatakan bahwa indikator ketepatan waktu memiliki persentase terendah dibandingkan dengan indikator lainnya yang merupakan penghambat efektivitas program Bantuan Pangan Non Tunai sehingga pelaksanannya tidak mencapai $100 \%$. Hal ini menunjukkan bahwa waktu penyaluran bantuan tidak baik sehingga sebagian masyarakat tidak dapat memperbaiki kesejahteraannya.

Berdasarkan dari data rekapitulasi kuisioner penelitian yang dilaksanakan di Desa Maddenra Kecamatan Kulo Kabupaten Sidenreng Rappang, pada kesejahteraan masyarakat (keluarga penerima manfaat) diperoleh rata-rata persentase yaitu $60 \%$ dengan kategori kurang baik, hal ini berarti indikator kesejahteraan masyarakat yang seharusnya mencapai 100\% namun masih ada $40 \%$ persentase yang tidak tercapai. Menurut Arifin dan Soesatyo (2020:41-42) kesejahteraan adalah suatu keadaan dimana terpenuhinya kebutuhan masyarakat secara baik pangan, sandang, dan papan. Dilihat dari item kuisioner diperoleh data responden bahwa indikator kebutuhan pangan, sandang, dan papan dengan persentase $60 \%$ dalam kategori kurang baik ini menunjukkan bahwa kesejahteraan masyarakat di Desa Maddenra kurang baik.

Berdasarkan pada keputusan yang telah dipaparkan dalam pengujian hipotesis dapat dijelaskan bahwa $\mathrm{HO}$ ditolak dan Ha diterima dengan kata lain thitung > ttabel $(3.305>$ $2,008)$ artinya signifikan. Dari data tersebut dapat dikatakan bahwa Efektivitas Program Bantuan Pangan Non Tunai berpengaruh signifikan terhadap Kesejahteraan Masyarakat di Desa Maddenra Kecamatan Kulo Kabupaten Sidenreng Rappang memiliki pengaruh sebesar 17,6\% seperti yang ditunjukkan oleh tabel model summary dimana nilai Rsquare 0,176 atau 17,6 apabila efektivitas Program Bantuan Pangan Non Tunai dinilai kurang baik maka kesejahteraan masyarakat juga kurang baik.

\section{KESIMPULAN}

Berdasarkan pembahasa diatas, maka penulis menarik kesimpulan dengan uraian sebagai berikut :

1. Efektivitas Program Bantuan Pangan Non Tunai (BPNT) di Desa Maddenra Kecamatan Kulo Kabupaten Sidenreng Rappang diperoleh rata-rata persentase $56 \%$ termasuk dalam kategori "kurang baik". Berdasarkan hasil rekapitulasi kuisioner indikator efektivitas program yang 
seharusnya mencapai $100 \%$ namun terdapat $44 \%$ persentase sehingga tidak dapat tercapai kategori sangat baik.

2. Kesejahteraan masyarakat (keluarga penerima manfaat) diperoleh rata-rata persentase yaitu $60 \%$ termasuk dalam kategori "kurang baik", hal ini berarti indikator kesejahteraan masyarakat yang seharusnya mencapai $100 \%$ namun masih ada $40 \%$ persentase yang tidak tercapai.

3. Efektivitas Program Bantuan Pangan Non Tunai (BPNT) memiliki pengaruh signifikan terhadap Kesejahteraan Masyarakat (keluarga penerima manfaat). Hal ini dapat dilihat dari uji t, dimana thitung $>$ ttabel atau $3.305>2,008$ maka $\mathrm{HO}$ ditolak dan $\mathrm{Ha}$ diterima, artinya signifikan. Memiliki pengaruh sebesar $17,6 \%$ seperti yang ditunjukkan oleh tabel model summary dimana nilai Rsquare 0,176 atau $17,6 \%$ besarnya pengaruh variabel $X$ terhadap variabel $\mathrm{Y}$.

\section{E. REFERENSI}

Ahmad, Jamaluddin. 2015. Metode Penelitian Administrasi Publik. Yogyakarta :Gava Media.

Arifin, Syamsul dan Soesatyo, Yoyok. 2020. Pertumbuhan Ekonomi, Tingkat Pengangguran, Dan Konsumsi, Dalam Bingkai Kesejahteraan Masyarakat. Jawa Tengah: CV. Pena Persada Redaksi.

Ghafur, Waryono Abdul, dkk. 2012. Interkoneksi Islam Dan Kesejahteraan Sosial: teori, Pendekatan dan Studi IImu. Yogyakarta: Samudra Biru.

Ghozali, Imam. 2009. "Aplikasi Analisis Multivariate dengan Program SPSS ". Semarang : UNDIP.

Nazir. 2005. Manajemen Kualitas Pelayanan. STIA LAN Press, Jakarta.

Qurtubi. Ahmad. 2019. Administrasi Pendidikan (Tinjauan Teori \& Implementasi). Surabaya: CV. Jakad Media Publishing.

Rostiana, Endang dan Djulius Horas. 2018. Perencanaan dan Pengelolaan Keuangan Dalam Mewujudkan Keluarga Sejahtera. Yogyakarta: Diandra Kreatif.

Simamora, Roymond H. 2008. Buku Ajar Pendidikan Dalam Keperawatan. Jakarta: Buku Kedokteran EGC.

Sugiyono. 2016. Metode Penelitian Kuantitatif, Kualitatif dan R\&D. Bandung: PT Alfabet.
p-ISSN 2302-0970

e-ISSN 2723-0201

Zainuddin. 2017. Teori-teori Mutakhir Dalam Perspektif IImu Administrasi Publik. Makassar: Phinatama Media (Phinisi Utama Media).

Jurnal

Darmawan, R., \& Adiwidjaja, I. (2019). Efektivitas Kebijakan Dinas Sosial Dalam Menanggulangi PMKS Khusus ODGJ Terlantar Di Kota Batu. Jurnal IImu Sosial Dan IImu Politik, 8(4), 165174.

Dewi, D. K., Kuncoro, B., \& Mahendradi, R. (2018). Efekrivitas Dan Efisiensi EProcurement Dalam ProsesS Pengadaan Barang/Jasa Di Kabupaten Magelang. JMAN Jurnal Mahasiswa Administrasi Negara, 2(1), 138-149.

Fahreza, Arifin, J., \& Suryani, L. (2019). Effectiveness Of Prosperous Rice Program ( RASTRA) In Binangon Village, Muara Komam District Paser Regency. Jurnal Administrasi Publik Dan Administrsi Bisnis, 2(2), 566-584.

Gultom, H., Kindangen, P., \& Kawung, G. (2020). Analisis Pengaruh Program Bantuan Pangan Non Tunai (BPNT) Dan Program Keluarga HarapanPKH) Terhadap Kemiskinan Di Kabupaten Minahasa Tenggara. Jurnal Pembangunan Ekonomi Dan Keuangan Daerah, 20(04), 39-53.

Karambut, C. A. (2017). Pengaruh Keselamatan Dan Kesehatan Kerja Terhadap Efektivitas Kerja Pada Pt. Asri Griya Utama, Project Holland Village Manado. Jurnal Manis Volume!, 1(2), 20-37.

Pertiwi, M., \& Nurcahyanto, H. (2017). Efektivitas Program BPJS Kesehatan Di Kota Semarang (Studi Kasus pada Pasien Pengguna Jasa BPJS Kesehatan di Puskesmas Srondol). Journal of Public Policy and Management Review, 6(2), 3

Ramadhan, T. (2018). Efektivitas Program BPNT Terhadap Peningkatan Kesejahteraan Masyarakat Kecamatan Tampan Pekanbaru. JOM FISIP, 5, 114.

Saptanto, S., Kurniawan, T., Putri, H. M., \& Tajerin. (2017). Analisis Penentuan Indikator Kunci Dalam Perhitungan Indeks Kesejahteraan Masyarakata Kelautan Dan Perikanan. Jurnal Kebijakan Sosial Ekonomi Kelautan Dan Perikanan, 7(1), 51. 8 